\title{
NAZARIYAT Then \\ Like a Swiss Clockwork in the Desert: A Review of Moshe M. Pavlov's Books on Abū al-Barakāt al-Baghdādī
}

Moshe M. Pavlov. Abū'l-Barakāt al-Baghdādī's Scientific Philosophy: The Kitāb al-Mu'tabar. Abingdon, UK and New York, NY: Routledge, 2016. 370 pages. ISBN: 9781138640450.

Moshe M. Pavlov. Abū'l-Barakāt al-Baghdādī's Metaphysical Philosophy: The Kitāb al-Mu'tabar. Abingdon, UK and New York, NY: Routledge, 2017. 387 pages. ISBN: 9781138640498.

\section{Pauline Froissart}

This review essay covers Moshe M. Pavlov's two-volume project on the twelfth-century Jewish philosopher Abū al-Barakāt al-Baghdādī's (d. ca. 547/1152) magnum opus, the Kitāb al-Mu'tabar: Abū'l-Barakāt al-Baghdādī's Scientific Philosophy (hereinafter ASP) and Abü'l-Barakāt al-Baghdādī's Metaphysical Philosophy (hereinafter AMP). Although the structure of these two volumes allows an independent reading of only one of them - and even of separate chapters from them - I have privileged a common review of them in order to provide an evaluation of the project as a whole rather than one of its aspects. I will expand my evaluation after a brief summary of the two books' content.

The general project seeks to detail the systematic character of Abū al-Barakāt's philosophical endeavor - more particularly the high level of interconnection between his scientific and metaphysical positions - as well as the distinctively Jewish nature of its purpose (at the exclusion of Islamic elements) (ASP, 7). By way of an introduction, the first volume includes a general presentation of the whole project, a biographical account of Abū al-Barakāt al-Baghdādì, and a broad overview of the

PhD Candidate in Islamic Philosophy, McGill University, Institute of Islamic Studies.

Correspondence: pauline.froissart@mail.mcgill.ca. 
history of philosophy from Plato and Aristotle to our twelfth-century thinker. In the biographical description, the author, based on Moshe Gil's work, ${ }^{1}$ enjoins one to identify Abū al-Barakāt with the Talmudist Rabbi Baruch ben Melekh and to adopt the hypothesis of the latter's coerced conversion to Islam. The main part of the first volume is divided between an exposition of the philosopher's ontological and epistemological critical stances against the Aristotelian tradition and a detailed presentation of his contributions with regard to the principles of sciences, understood as physics, psychology, and logic. The second volume is dedicated to the metaphysical accounts developed in the first book of the metaphysical part of the Kitāb al-Mu'tabar.

The presentation order of the philosophical topics in the two volumes closely follows the Kitāb al-Mu'tabar's own content structure. The two volumes take part in the same general project of proving the work's systematic nature as the ontological and epistemological developments elaborated in the scientific part acquire their full meaning, once recaptured at the metaphysical level and, more specifically, once they reach the "culminating cumulative conclusion" of the whole system and its ontological and epistemological consequences are plainly grasped (ASP, xi). This culminating cumulative conclusion consists in the possibility for humanity to access a special kind of cognition of God's ipseity, a notion conceived of as the equivalent of the Jewish Shem ha-Meforash, the Special Name of God. According to the author, Abū alBarakāt's identification with the highly erudite Talmudist and strictly observant Jew Rabbi Baruch ben Melekh, as well as the culmination of his system in an authentically Jewish teaching, demonstrate the Kitāb al-Mu'tabar's distinctively Jewish identity.

The author's general approach consists primarily of an in-depth internal analysis of the Kitāb al-Mu'tabar, which highlights its rigorously systematic nature and recapitulates the system's main contributions to the concepts and problematics specific to analytical philosophy. His close reading manifests many valuable insights on the minute structure of Abū al-Barakāt's system, and his endeavor to actualize its main issues and conclusions in contemporary debates deserves praise with regard to the level of philosophical ingenuity such a task requires. Nevertheless, the entire project is, unfortunately, deeply undermined by an insufficient and inadequate historical contextualization. When the author feels the need to cover briefly potential sources that were influential on our twelfth-century thinker, most times he mobilizes references to Plato (d. $347 \mathrm{BCE}$ ) and Aristotle (d. $322 \mathrm{BCE}$ ) without further justification. The obviously massive contributions of Abū al-Barakāt's Muslim predecessors and Late Antique Neoplatonists to the shaping of his thought are 
almost invariably passed over. I will develop two examples selected from each volume to illustrate this insufficient and inadequate historical contextualization by referring to two cases in which Avicenna's (d. 428/1037) obvious influence on the development and structuration of Abū al-Barakāt's particular points of doctrine are completely set aside by the author, who provides no satisfactory justification for doing so.

In $A S P$, in the first section of the chapter dealing with the psychological part of Abū al-Barakāt's scientific project - "Epistemological ascertainment of psychology" - a section designed to provide a historical introduction to the chapter's content, the author dedicates one and a half pages out of a sixteen-page section to Avicenna's conception of the soul (ASP, 235-36) while Plato, Aristotle, and John Philoponus (d. ca. 570) enjoy a total of seven pages (ASP, 228-35). Avicenna's conception of the soul is presented as a mere combination of "the Aristotelian hierarchical notion with the notion of the ego derived from Philoponus" (ASP, 235). This subsection simply concludes on the difference between the two philosophers' respective definition of the soul. The baffling character of this very limited treatment of Avicenna's influence on Abū al-Barakāt's psychology, one that is completely disproportionate with regard to its importance, can be easily spelled out if we compare it with how the recent scholarship to which Pavlov should have access ${ }^{2}-$ as well as the less recent research of which he obviously made use ${ }^{3}$ - covered this specific topic.

In the second chapter of $A M P$, dealing first with the question of time, the author highlights Abū al-Barakāt's significant use of a thought experiment ( $A M P, 90-93)$ that he describes as "an unusual attempt in medieval philosophy to explicate the nature of time by an operational method of a thought experiment" ( $A M P, 90)$. In the corresponding note to the quoted sentence, he adds that thought experiments were "not prominent before Ernst Mach [1838-1916]" (AMP, 130, note 32), that it is to say, not before the end of the nineteenth century. I will not elaborate here upon the prominence of thought experiments or the lack thereof before Mach, ${ }^{4}$ but

2 See, for example, Jari Kaukua's article and monograph on closely related topics that vetted the nature of Avicenna's influence on Abū al-Barakāt's psychology: Jari Kaukua, Self-awareness in Islamic Philosophy: Avicenna and Beyond (New York: Cambridge University Press, 2015), 104-23; Jari Kaukua, "Self, Agent, Soul: Abū al-Barakāt al-Baghdādī's Critical Reception of Avicennian Psychology," in Subjectivity and Selfhood in Medieval and Early Modern Philosophy, ed. Jari Kaujua and Tomas Ekenberg (Switzerland: Springer, 2016), 75-89.

3 An article by Shlomo Pines, with whom the author is frequently critically engaged throughout the two volumes, appears in his collected Studies in Abü'l-Barakät al-Baghdädī's Physics and Metaphysics. Entitled "La conception de la conscience de soi chez Avicenne et chez Abū'l-Barakāt al-Baghdādī," it deals explicitly with this influence. See Shlomo Pines, "La conception de la conscience de soi chez Avicenne et chez Abū'l-Barakāt al-Baghdādī," in Studies in Abü'l-Barakāt al-Baghdādī's Physics and Metaphysics (Jerusalem: Magnes Press and Leiden: E. J. Brill, 1979), 181-258. 
rather will focus on the fact that the author bases his claims on Abū al-Barakāt's originality throughout the two volumes on remarks of this kind.

I have selected this last example, which could have been considered as simply anecdotal, because it eloquently illustrates how Pavlov's inadequate historical contextualization makes his statements about Abū al-Barakāt's originality, which I still consider undeniable, dubious. Indeed, the only mention of the well-known "Floating / Flying Man argument" developed in different versions by Avicenna seems to me to be amply sufficient to question the author's statement about the absence of thought experiments in medieval works, more specifically in the works to which Abū al-Barakāt had direct and recurrent access. ${ }^{5}$

Due to the format's requirement of a review essay, I have to restrict my presentation to these two examples to give the reader some idea of the lack of historical contextualization toward which I am pointing. In view of the blatant absence of any critical discussion on the potential influences of the figures who shaped the 800-year history of philosophy that separate Abū al-Barakāt from Aristotle, concluding on the non-existence of Islamic elements within the former's philosophical endeavor sounds more analogous to a petitio principii than a research hypothesis. This lack of proper historical contextualization makes Pavlov's repetitive claims on the thinker's radical originality very dubious.

Even though I am also deeply convinced of the uniqueness of Abū al-Barakāt's philosophical enterprise, removing it from its adequate historical framework makes it very hazardous to determine the nature and extension of its originality. An internal analysis of the text, regardless of how rigorous and minute it can be, is not enough to address the issue of potential historical influences. Many of the most significant sources were left unidentified simply because they were, for example, too obvious for the contemporary reader to require further labelling. Furthermore, the way a philosopher may refer to his/her predecessors more often counts as a rhetorical stage-setting than as a meticulous approach to situate oneself objectively - if only it were possible - within the scope of the history of philosophy.

in Methodological and Historical Contexts would require a little bit more caution before formulating plain statements of this kind. See Katerina Ierodiakonou and Sophie Roux, Thought Experiments in Methodological and Historical Contexts (Leiden: Brill, 2011).

5 My point here does not require me to address the debated issue of Avicenna's philosophical purpose behind his "Floating / Flying Man" thought experiment. However, to my knowledge the nature of his thought experiment has never been challenged. See Michael E. Marmura, "Avicenna's 'Flying Man' in Context, The Monist 69, no. 3 (1986): 383-95. Moreover, Jon McGinnis has recently addressed the variety of the use of these experiments by Muslims philosophers, in particular by Avicenna. See Jon McGinnis, "Experimental Thoughts about Thought Experiments in Medieval Islam," PhilSci Archives, accessed online on 28 August 2016, http://philsci-archive.pitt.edu/12391/. 
With regard to the three main components of these two books' thesis - the Kitāb al-Mu'tabar's systematic character, its culminating point in a special cognition of God's ipseity, and the distinctively Jewish nature of Abū al-Barakāt's philosophy - only the first one has been demonstrated convincingly. I would only express my reserve with respect to the underlying notion of the systematicity at play in the author's demonstration - without contesting his final conclusion - a notion that appeared to me as too embedded within the worldview of analytical philosophy to avoid creating a sensation of an anachronism once used in a medieval work. I also agree that the Kitāb al-Mu'tabar's structure manifests a deep cohesion, touching, as Pavlov also alluded to, to a feeling of organicity. Nevertheless, the standard of systematicity toward which this philosophical treatise tends is obviously alien to the standard developed across the last century in analytical philosophy, which is mostly based on a framework conditioned by the development of modern scientific practices.

I consider the two other parts of this project's thesis as stimulating research hypotheses that could have opened new perspectives and raised new questions on this philosophical masterpiece. Indeed, postulating a first and foremost Jewish character and impetus to Abū al-Barakāt's philosophical enterprise could have, for example, forced the uncovering of unidentified Jewish sources and figures who could have remained unnoticed under the first layers of more obvious Islamic and Neoplatonist influences. Nevertheless, the author's tone and way of exposition indicate that these two statements are more truths that he has to convey rather than hypotheses designed to dynamize the field. Throughout the two volumes, these two aspects of the thesis are repeated at every crucial step of development, but without any significant addition or being seriously confronted with counterarguments and narratives. These numerous repetitions may be explained by the editorial choice to conceive of the chapters as independent entities that could be read separately; however, this technique has two side-effects: It significantly raises the burden of a complete reading of the two volumes and gives the impression of clouding the minutiae points of the demonstration.

In conclusion, even though the author manages to prove the main point of his thesis - the Kitāb al-Mu'tabar's outstanding systematicity - through a careful internal analysis of the work, the rest of his conclusions are deeply undermined by a blatant lack of sufficient historical contextualization - a blatant lack that makes these two volumes too hazardous to recommend to an audience not sufficiently initiated into Islamic philosophy and too weak to raise interest among a more advanced readership. 